\title{
Biopolitical Borders and the State of Exception in the European Migration 'Crisis'
}

\section{Dr Daria Davitti}

\section{Introduction}

In this article I examine the current European refugee 'crisis' by challenging, from a theoretical perspective, the way in which the European Union (EU) has used the increased number of deaths in the Mediterranean as an opportunity to frame recent migration flows as an emergency which, by definition, can only be addressed through the adoption of exceptional measures. Throughout the article, I engage with the work of Giorgio Agamben ${ }^{1}$ on biopolitics ${ }^{2}$ and state of exception to illustrate, first, the need to rethink the way in which borders are defined and used (e.g. externalised) within the context of the European refugee 'crisis'. Second, Agamben's work is useful to understand what moves the externalisation and privatisation of migration, and to ascertain how international law has enabled the emergence of this 'crisis' framing, ${ }^{3}$ whilst at the same time partly losing its ability to challenge EU policies. I argue that the posture of humanitarianism adopted by the EU masks the fact that the appalling situation in which refugees are abandoned is not accidental but inherent to the enhanced measures adopted by the EU and its member states as part of the European Agenda.

Whilst Agamben's work has been broadly deployed in the context of forced migration by scholars from various disciplines, ${ }^{4}$ his theory remains controversial ${ }^{5}$ and perhaps not fully understood. I see his work as part of broader interrogations on the relationship between biopolitics and crisis, as developed by the work of contemporary Italian thinkers (referred to by Roberto Esposito as Italian Theory or 'Italian Thought'), ${ }^{6}$ and as such useful to examine the

\footnotetext{
All websites were last accessed on 19 May 2018, unless otherwise stated.

${ }^{1}$ Whilst engaging with various publications by this well-known philosopher, I will focus mostly on the arguments that he develops in Homo Sacer: Sovereign Power and Bare Life (Stanford University Press, 1998) and in State of Exception (University of Chicago Press, 2005).

2 I understand Agamben's work on biopolitics as complementing and further developing Michel Foucault's contributions on the topic, in particular M Foucault, Security, Territory, Population: Lectures at the Collège de France, 1977-1978 (AIAA, 2007) and M Foucault, The Birth of Biopolitics: Lectures at the Collège de France, 1978-1879 (Palgrave Macmillan, 2008).

${ }^{3}$ H Charlesworth, 'International Law: A Discipline of Crisis' (2002) 65 Modern Law Review 377.

${ }^{4}$ See e.g. N Vaughan-Williams, Europe's Border Crisis: Biopolitical Security and Beyond (Oxford University Press, 2015). See also M B Salter, 'Theory of the /: The Suture and Critical Border Studies' (2012) 17 Geopolitics Journal 734.

${ }^{5}$ See e.g. F Johns, 'Guantanamo Bay and the Annihilation of the Exception' (2005) 16 European Journal of International Law 613.

${ }^{6}$ See R Esposito, Da fuori: una filosofia per l'Europa (Einaudi, 2016), where Esposito suggests that the 'Italian Thought' offers a realist lens to interrogate current political conflicts and tensions, including the European response to incoming migration flows. See also R Esposito, Living Thought: The Origins and Actuality of Italian Philosophy (Stanford University Press, 2012)
} 
role of international law in enabling, shaping and maintaining the ordering nature of violence ${ }^{7}$ of EU migration policies, including in their current dimensions of externalisation. This article is therefore based on two main premises which are tested by applying some of the conceptual tools offered by Agamben or, to use his own terminology, his interpretative paradigms. ${ }^{8}$ The first premise is that the fortified walls and militarised borders erected in response to the latest European migration 'crisis' reflect the waning of state sovereignty ${ }^{9}$ within the transnational global order. Crucially, however, these physical infrastructures also serve the purpose of pushing the borders beyond the geographical confines of the EU, ${ }^{10}$ by diverting migratory flows towards pre-established processing 'hotspots' ${ }^{11}$ in Greece and Italy, or to countries of transit or origin in exchange for so-called development aid. ${ }^{12}$ Refugees are thus redirected towards more dangerous routes: ${ }^{13}$ on land, where they are more exposed to the violence of

\footnotetext{
${ }^{7}$ See C Salzani, 'From Benjamin's bloßes Leben to Agamben's Nuda Vita: A Genealogy' in B Moran and C Salzani (eds) Towards the Critique of Violence: Walter Banjamin and Giorgio Agamben (Bloomsbury, 2015) 109.

${ }^{8}$ In his lecture 'What is a Paradigm?' at the European Graduate School in August 2002, Agamben looks at Kuhn's use of the term paradigm, first as 'designating what the members of a certain scientific community have in common, that is to say, the whole of techniques, patents and values shared by the members of the community'. Second, in its oldest meaning, a paradigm 'can guide the investigation also in the absence of rule. (...) The paradigm is in this sense just an example, a single phenomenon, a singularity, which can be repeated and thus acquires the capability of tacitly modeling the behavior and the practice of scientists'. Transcript of the lecture available at www.maxvanmanen.com/files/2014/03/Agamben-What-is-a-paradigm1.pdf.

9 W Brown, Walled States, Waning Sovereignty (Zone Books, 2010). See however Brown's more recent reflections on how this thesis may be inadequate to fully analyse recent EU border developments. She argues that 'States today are concerned not only with the concrete political, social and economic costs or benefits of immigration, but with its potential impacts on the nation's attractiveness to potential creditors and investors': see R Jones et al, 'Interventions on the State of Sovereignty at the Border' (2017) 59 Political Geography 1, 3. See also M Feher's argument in 'The Critical State of the Union' (2016), available at www.nearfuturesonline.org/thecritical-state-of-the-union/, which inspires Brown's perspective: Fehler claims that, since the recession of 2009, EU policy-making has been mostly dominated by two fundamental preoccupations: 'attracting international investors while repelling undesirable migrants'.

${ }^{10}$ See T Gammeltoft-Hansen and J Vedsted-Hansen (eds) Human Rights and the Dark Side of Globalisation: Transnational Law Enforcement and Migration Control (Routledge, 2017), especially part III.

${ }^{11}$ ECRE et al, 'The Implementation of the hotspots in Italy and Greece: A Study' 5 December 2016, available at http://www.ecre.org/wp-content/uploads/2016/12/HOTSPOTS-Report-5.12.2016..pdf.

${ }^{12}$ D Davitti and A La Chimia, 'A Lesser Evil? The European Agenda on Migration and the Use of Aid Funding for Migration Control' (2015) 10 Irish Yearbook of International Law 133. See also Report of the UN Special Representative of the Secretary-General on Migration (3 February 2017) UN Doc A/71/728, para 39: ‘...when sending people back to their countries of origin becomes the primary goal of countries of destination, negotiations with the former can easily descend into a standoff, or an exercise of mutual blackmail. Furthermore, making unrelated areas of cooperation, such as trade and development aid, contingent on a country's cooperation with regard to the return and readmission of migrants is short-sighted and wrong, and may actually strengthen some of the underlying drivers of irregular migration'. See also N El Qadim, 'Lutte contre l'immigration irrégulière et conditionnalité de l'aide au développement' (2018) 30 Migrations Société 109.

${ }^{13} \mathrm{R}$ Andersson, Illegality, Inc. Clandestine Migration and the Business of Bordering Europe (University of California Press, 2014). Medicins Sans Frontieres, 'One Year from the EU-Turkey Deal: Challenging the EU's Alternative Facts' (March 2017), available at www.msf.org/en/article/one-year-after-eu-turkey-deal-migrantsand-asylum-seekers-are-paying-price-their-health. For an understanding of some of the push factors and of the features of these routes, see L Napoleoni, Merchants of Men: How Kidnapping, Ransom and Trafficking Funds Terrorism and Isis (Atlantic Books, 2017).
} 
border guards and traffickers $;{ }^{14}$ and at sea, where the line between rescue operations and pushbacks is increasingly blurred. ${ }^{15}$ Agamben's work, in this context, is useful to make visible the way in which EU policies justify and enable violent externalisation measures, not least through increased cooperation with third countries in the attempt to avoid state responsibility for possible wrongful conduct. The second premise is that whilst refugees are managed and controlled along these routes, international obligations to provide refugee protection are circumvented, enveloped as they are in a 'state of willed exception'. ${ }^{16}$ In what follows I examine the way in which state sovereignty, in its current shifting and fluid form, ${ }^{17}$ operates to construct biopolitical borders, ${ }^{18}$ and argue that these borders are liquid, ${ }^{19}$ that is they are characterised by non-linear (externalised and outsourced) enforcement infrastructures. These are both physical infrastructures (such as corridors and spaces of confinement and connection through which refugees are 'managed'); ${ }^{20}$ and borderline legal infrastructures aimed at

\footnotetext{
${ }^{14}$ See UN General Assembly, 'Unlawful Death of Refugees and Migrants: Report of the Special Rapporteur of the Human Rights Council on extrajudicial, summary or arbitrary executions, Agnes Callamard' (15 August 2017) UN Doc A/72/335. See also UN Office of the High Commissioner for Human Rights, 'UN Human Rights Chief: Suffering of Migrants in Libya Outrage to Conscience of Humanity', Press Release of 11 November 2017, available at http://www.ohchr.org/EN/NewsEvents/Pages/DisplayNews.aspx?NewsID=22393\&LangID=E denouncing the abuses suffered by migrants in Libya, and the assistance provided by the EU and Italy to the Libyan Coast Guard 'to intercept migrant boats in the Mediterranean, including in international waters, despite concerns raised by human rights groups that this would condemn more migrants to arbitrary and indefinite detention and expose them to torture, rape, forced labour, exploitation and extortion'.

${ }^{15}$ See e.g. the controversial draft Code of Conduct proposed by Italy in July 2017 to regulate non-governmental organisations involved in search and rescue operations in the Mediterranean Sea, available at https://www.humanrightsatsea.org/wp-content/uploads/2017/07/2017070516-EU-Code-of-Conduct.pdf. $\quad$ On allegations against NGOs for colluding with human traffickers, see Italian Association of Juridical Studies on Migration/ASGI, 'Position Paper on the Proposed Code of Conduct for NGOs Involved in Migrants' Rescue at Sea' available at https://www.asgi.it/wp-content/uploads/2017/07/Draft-ASGI-Position-Paper_Final_EN.pdf. See also Papastavridis, 'Rescuing Migrants at Sea and the Law of International Responsibility' in GammeltoftHansen and Vedsted-Hansen, supra note 10.

${ }^{16} \mathrm{G}$ Agamben, supra note 1 (2005).

${ }^{17} \mathrm{~W}$ Brown, Undoing the Demos (Zone Books, 2015), where she describes how, at the end of the Cold War, neoliberalism emerged as a new form of governmental reason, and how this 'would inaugurate democracy's conceptual unmooring and substantive embowelment'. In her view, neoliberalism not only fills the meaning of democracy with market values, it also 'assaults the principles, practices, cultures, subjects, and institutions of democracy understood as rule by the people. And more than merely cutting away the flesh of liberal democracy, neoliberalism also cauterizes democracy's more radical expressions'.

${ }^{18}$ Vaughan-Williams, supra note 4 at 34-43.

${ }^{19}$ I draw the concept of 'liquity' from Zygmunt Bauman, and more specifically from his critique of how, in liquid modernity, globalisation and privatisation affect society and ultimately our lives, including in terms of how life is organised in a fragmented way, with a focus on adaptability under the current conditions of endemic uncertainty. See e.g. Z Bauman, Liquid Modernity (Polity, 2000); and Z Bauman, Liquid Times: Living in an Age of Uncertainty (Polity, 2013).

${ }^{20}$ See R Jones et al, 'Interventions on the State of Sovereignty at the Border' (2017) 59 Political Geography 1, supra note 9: the article is divided into various contributions by seven authors who look at different geographical spaces and manifestations of the borderscape. For instance, Wendy Brown looks at border walls as semiotic responses to waning state sovereignty, but also as 'pieces in complex sovereignty contests between national and postnational powers of political determination, economic arrangements and demographic composition'. Emily Gilbert examines, in her contribution, the increased securitisation and militarisation of the border and the way in
} 
avoiding international obligations (such as concepts of 'safe third country' or forced returns measures through agreements aimed at readmission). The juxtaposition of liquidity and infrastructure forces us to debunk conventional political narratives which are pervasive in current migration 'crisis' discourses. Most importantly, as I explain in this article, I understand these infrastructures as the physical and legal embodiment of the state of exception, described by Agamben in his work with the image of 'the camp'.

This article is divided into two substantive parts: in part I, I engage with Agamben's conceptualisation of biopower and biopolitics - and crucially with his understanding of Foucault's theory of sovereign power to 'make live and let die" 21 - to analyse the framing of the refugee situation in Europe as a 'crisis' and of refugees themselves as a security threat. I then trace the shift from such 'crisis' framing to the state of exception, which enables violent and repressive measures to manage and externalise migration. In part II, based on Agamben's paradigm of the camp, I examine the displacement of the EU borders and discuss the physical and legal infrastructures characterising what I call the liquid borders of the EU. Going beyond a mechanical application of Agamben's theory to EU migration policies, I argue that analysing the implications of the legal techniques which underpin the liquidity of the EU borders is as important as identifying the physical infrastructures through which refugees are controlled and managed: both complement each other and perversely crystallise and justify EU policies, not least through the language of humanitarianism. They also maintain what Agamben calls a threshold of indistinction ${ }^{22}$ in which refugees are both equally banned and abandoned. On this threshold we see 'a regime of the law within which the norm is valid but cannot be applied (since it has no force), and where the acts that do not have the value of the law acquire the force of law'. ${ }^{23}$ As I will evidence in this article, both infrastructures are indeed essential to fully understand the role of international law in enabling these EU policies and maintaining the ordering nature of violence of the European Agenda.

\section{The State of Exception in the European Agenda on Migration}

In this section I engage with the work of Giorgio Agamben on biopower, biopolitics and state

which privatisation and bilateral agreements to outsource migration de facto result in the erasure of the borders and in a re-articulation of state sovereignty.

${ }^{21}$ M Foucault, Society Must Be Defended: Lectures at the Collège de France, 1975-76 (Penguin, 2004$) 15$.

${ }^{22}$ G Agamben, Means Without End: Notes on Politics: What is a Camp? (University of Minnesota Press, 2000), $171-2$.

${ }^{23}$ G Agamben, 'The State of Emergency', transcript from a lecture at the Centre Roland-Barthes (Universite Paris VII, Denis-Diderot) in 2002, available at www.generation-online.org/p/fpagambenschmitt.htm. 
of exception, understood as complementing rather than correcting Foucault's work. ${ }^{24}$ More specifically, I look at the way in which Agamben, and in part Judith Butler, elaborate on Foucault's argument that the sovereign right to 'take life or let live' has transformed itself into the power 'to make live and let die'. According to Foucault during the seventeenth and eighteenth centuries, a new form of sovereign power emerges which, through technologies of surveillance, 'exerts a positive influence on life, that endeavours to administer, optimize, and multiply it, subjecting it to precise controls and comprehensive regulations'. ${ }^{25}$ Foucault used the term governmentality to describe this intervention on life. Towards the second half of the eighteenth century, then, these techniques of power were accompanied by disciplinary surveillance aimed at taking control of life and biological processes of the population in order to 'regularise' them: what Foucault termed 'making live and letting die'. ${ }^{26}$ Various scholars have argued that a contemporary application of Foucault requires, to a certain extent, a broader conceptualisation of biopower, capable of reflecting the changes that governmentality has undergone. ${ }^{27}$ As I discuss later in this section when contextualising this shift with examples from current EU policies, Agamben and Butler see that a contemporary examination of how political power works would interrogate the new forms of 'systematic negligence or redistribution of geopolitical power' through which entire populations are left starving or, in other ways, left to die. ${ }^{28}$ Throughout these new forms of systematic neglect and shifts in geopolitical power, the sovereign power over life continues to exist and never disappears entirely, ${ }^{29}$ as it operates to engender a situation of emergency so that it can then 'intervene and restore security in the right way'. ${ }^{30}$

In my analysis I use this contextualisation of Foucault's work as a framework to examine the

\footnotetext{
${ }^{24}$ Various authors have criticised Agamben's reading of Foucault, in particular his use of biopolitical power. See e.g. P Patton, 'Agamben and Foucault on Biopower and Biopolitics' in M Calarco and S De Caroli (eds), Giorgio Agamben: Sovereingty and Life (Stanford University Press, 2007) 203; K Genel, 'The Question of Biopower: Foucault and Agamben (2006) 18 Rethinking Marxism 43; and P Fitzpatrick, 'These Mad Abandon'd Times' (2001) 30 Economy and Society 255. I read Agamben's work, however, as compatible with Foucault's and a continuation thereof.

${ }^{25}$ Foucault, Society Must Be Defended, supra note 21, 137.

${ }^{26} \mathrm{ibid}, 242$.

${ }^{27}$ See e.g. S Mezzadra et al (eds) The Biopolitics of Development: Reading Michel Foucault in the Postcolonial Present (Springer, 2013) 4, where the editors posit that to fully understand the way in which biopower operates in a neoliberal context, we need to understand that neoliberalism's 'claims to legitimacy depend less on its abilities to promote the prosperity of human life and more that of the life of the biosphere. The correlations of economy, well-being, freedom, security and biospheric life in and among neoliberal regimes of practice and representation comprise the contemporary foundations of its biopolitics'.

${ }^{28}$ See lecture by Judith Butler and Giorgio Agamben on 'Eichmann, Law and Justice' (European Graduate School, 2009), available at www.youtube.com/watch?v=Nw9zhuLLq_E.

${ }^{29} \mathrm{ibid}$

${ }^{30}$ U Raulff, 'An Interview with Giorgio Agamben' (2004) 5 German Law Journal 609, 609.
} 
protracted, and to an extent normalised, state of 'crisis' that has delineated itself along the EU borders. This understanding of 'crisis', as evidenced below, has in turn enabled the adoption and implementation of EU migration measures that, although couched in humanitarian language, have the aim of preventing people from reaching the $\mathrm{EU}^{31}$ and, when they do, of swiftly returning them to non-EU countries of origin or transit. I argue that the role of international law in this 'crisis' framing needs to be problematized and made visible ${ }^{32}$ as it contributes to the violent transformation of the EU borderscape. ${ }^{33}$ EU borders have essentially become liquid borders, in that they have (at least partially) lost their spatial and territorial significance as well as their legal and political meaning, as migration controls are increasingly outsourced. From the perspective of international law the crossing of the border to seek international protection has partly lost its importance, as the EU and its member states increasingly rely on readmission and return policies aimed at externalising migration control. ${ }^{34}$ Before examining in section II the role of international law in both enabling and maintaining the presence of these liquid borders, I will analyse, from a theoretical and practical perspective, the phenomena that have paved the way for their existence.

\section{A. 'Crisis', Biopolitics and State of Exception}

The European Agenda on Migration (European Agenda) was launched in May 2015 in response to the death of approximately 1,850 people across the Mediterranean during the first five months of that year. ${ }^{35}$ The EU presented the European Agenda, and the draconian deterrent measures that it entrenched, ${ }^{36}$ as a necessary 'immediate action to prevent further losses of migrants' lives at sea'. With an expressed dual aim of 'saving lives and securing the external

\footnotetext{
${ }^{31}$ See D Davitti and M Fries, 'Offshore Processing and Complicity in Current EU Migration Policies (part 1 and part 2)' available at https://www.ejiltalk.org/offshore-processing-and-complicity-in-current-eu-migrationpolicies-part-2/.

${ }^{32}$ The seminal work by Charlesworth, describing how 'crises mould and are moulded by international law' is crucially relevant here: supra note 3 , at 377 .

${ }^{33}$ On the conceptualisation of the terms 'borderscape' and 'borderness', and on their biopolitical implications, see P Cuttitta, 'Bordering the Island Settings and Narratives of the Lampedusa Border Play' (2014) 13 ACME: An International E-Journal for Critical Geographies 196. See also C Brambilla et al (eds), Borderscaping: Images and Practices of Border Making (Routledge, 2015).

${ }^{34}$ JP Cassarino, 'Through the Looking Glass of a Troubling Rapprochement' (2016) 12 The Middle East in London 9; and JP Cassarino 'Réadmission des migrants: les faux-semblants des partenariats euro-africains' (2016) 16 Politique étrangère 25.

${ }^{35}$ According to UNHCR, 3,771 deaths occurred across the Mediterranean by the end of 2015, with 1,015,078 people attempting the crossing. As of October 2016, whilst the number of crossings had fallen sharply to 327,800, the number of lives lost at sea already amounted to 3,740. See http://www.unhcr.org/uk/news/latest/2016/10/580f3e684/mediterranean-death-toll-soars-2016-deadliestyear.html.

${ }^{36} \mathrm{~J}$ Hathaway and T Gammeltoft-Hansen, 'Non-Refoulement in a World of Cooperative Deterrence' (2015) 53 Columbia Journal of Transnational Law 235.
} 
borders' (including through enhanced return policies), ${ }^{37}$ the EU defined the situation across the Mediterranean employing the language of emergency and humanitarianism, and used this as an opportunity to crystallise over twenty years of EU policies aimed at the externalisation of migration. ${ }^{38}$ As part of the implementing measures of the European Agenda, for instance, the EU border agency Frontex became the European Border and Coast Guard, with a stronger mandate, additional equipment and extra funding; and Europol gained a stronger intelligence role in tackling criminal networks across the smuggling routes, supported by a network of Common Security and Defence Policy (CSDP) operations. ${ }^{39}$ Crucially, the European Agenda also launched a new hotspot system, whereby new facilities were established in 'frontline' member states (Greece and Italy) to 'swiftly identify, register and fingerprint arriving migrants and to assist investigation and dismantling migrant smuggling networks' ${ }^{40}$ Thus, whilst the situation at the Southern borders of Europe was depicted as a humanitarian emergency demanding immediate intervention, those same refugees-whose lives these enhanced EU measures were ostensibly devised to save-were simultaneously portrayed as a potential security threat. Whether implicitly in the language of EU officials, or more explicitly in political and media debates, they were in fact construed not only as potential terrorists, but also as a threat to the economic security of EU member states (at a time of protracted financial austerity); and to the identity of their citizens (at a time of increased populism, racism and xenophobia). ${ }^{41}$

As argued by Whyte in her in-depth study of Agamben's work, 'the convergence of humanitarianism and killing should serve as a provocation to rethink the contemporary relation between politics, and life and death, and to interrogate the intersection of a power to kill with a commitment to maintaining life'. ${ }^{42}$ Agamben's work on biopolitics and state of exception is apposite in examining, through the language of emergency and humanitarianism adopted by the EU in developing and implementing the draconian measures of the European Agenda, the

\footnotetext{
${ }^{37}$ See Communication from the Commission to the European Parliament, the Council, the European Economic and Social Committee and the Committee of the Regions, 'The European Agenda on Migration' (13 May 2015) $\operatorname{COM}(2015) 240$ final, available at https://ec.europa.eu/home-affairs/what-we-do/policies/european-agendamigration/proposal-implementation-package_en. See also European Commission, Migration and Home Affairs, European Agenda on Migration, available at https://ec.europa.eu/home-affairs/what-we-do/policies/europeanagenda-migration_en.

${ }^{38}$ Gammeltoft-Hansen and Vedsted-Hansen, supra note 10.

${ }^{39}$ European Agenda, supra note 37.

${ }^{40}$ European Commission, supra note 37.

${ }^{41}$ A Bank et al, 'The Political Dynamics of Human Mobility: Migration Out Of, As and Into Violence' (2017) 8 Global Policy 12.

42 J Whyte, Catastrophe and Redemption: The Political Thought of Giorgio Agamben (Suny Press, 2013) 19-20.
} 
continuing ability of sovereign power to kill whilst at the same time renewing its commitment to fostering life. ${ }^{43}$ Before analysing these policies in more detail, however, it is important to examine the way in which Agamben explores Foucault's understanding of biopolitics ${ }^{44}$ as an expression of the relation between politics and life and as a process by which "natural life begins to be included in the mechanisms and calculations of State power, and politics turns into biopolitics, ${ }^{45}$ In doing so Agamben revisits the way in which the ancient Greeks used the term $z o \bar{e}$ to refer to the mere biological aspect of life, natural life, 'the simple fact of living common to all living beings (animals, men, or gods) ${ }^{\prime} ; 6$ and the term bios to refer to 'the form or way of living proper to an individual or a group', 'a qualified life'. Bios related to the political life in the polis, within the state. Zoē was, by default, excluded from the polis and relegated to the oikos, the domestic sphere. ${ }^{47} \mathrm{~A}$ human being could only develop his/her full potential by being a member of the polis, and therefore by learning to navigate and inhabit the distinction between the private and public spheres, the separation between zoe and bios.

This division between natural and political life transforms certain categories of living beings into what Agamben terms 'bare life'. Bare life is distinct from zoè (natural reproductive life) and bios (political life) in that it is the direct result of a sovereign decision. ${ }^{48}$ As explained by Whyte,

[b]y bare life Agamben means a life that is politicized through the fact of its exclusion. Neither simply natural life nor political life, bare life is the threshold of articulation that enables the passage from one to the other. Like Water Benjamin's depiction of 'mere life' as a life exposed to the mythic violence of the law, Agamben's bare life is not a natural life but a life exposed to sovereign power and the threat of death. (...) In the transformation of Afghan civilians into subjects of military humanitarian intervention, to be killed or kept alive, we see one of many manifestations of this separation of biological life from forms of life. However contemporary these lives may be, in Agamben's view, we will not adequately understand them unless we address the division between life and politics inaugurated by Aristotle.

In his study of Foucault and of the way in which biological life becomes directly

\footnotetext{
43 ibid, 20.

${ }^{44}$ See mainly M Foucault, History of Sexuality: Volume I: An Introduction (Vintage Books, 1988) and M Foucault, Society Must Be Defended: Lectures at the Collége the France, supra note 21.

${ }^{45}$ Agamben (n 1, 1998) 3.

46 ibid 1.

47 ibid 2.

48 ibid 109. See also at 90: 'Neither political bios nor natural zoe, sacred life is the zone of indistinction in which $z o \bar{e}$ and bios constitute each other in including and excluding each other'.
} 
political,Agamben emphasises that this politicisation of bare life is to be understood not as a new phenomenon but as the original activity of sovereign power:

the inclusion of bare life in the political realm constitutes the original-if concealed - nucleus of sovereign power. It can even be said that the production of a biopolitical body is the original activity of sovereign power. In this sense, biopolitics is at least as old as the sovereign exception. Placing biological life at the center of its calculations, the modern State therefore does nothing other than bring to light the secret ties uniting power and bare life. ${ }^{49}$

In its current political expression, the intersections between natural, biological life $(z o \bar{e})$ and politics have become more visible in the way in which the state regulates, controls and manages people's lives. The focus and insistence of sovereign powers on regulating the biological life of people reproduces bare lives, and in turn these bare lives are exposed to violence and death. According to Agamben, therefore, the fracture and separation between zoe and bios continue to characterize modern Western politics: what is decisive and innovative, it follows, is not so much the inclusion of zoe into the political sphere or that life becomes the main object of the calculations of state power but that:

together with the process by which the exception everywhere becomes the rule, the realm of bare life - which is originally situated at the margins of the political order-gradually begins to coincide with the political realm, and exclusion and inclusion, outside and inside, bios and zoē, right and fact, enter a zone of irreducible indistinction. At once excluding bare life from and capturing it within the political order, the state of exception actually constituted, in its very separateness, the hidden foundation on which the entire political system rested. ${ }^{50}$

Thus for Agamben there is an inherent danger in the politicisation of life, 'which threatens to reduce humanity to biological life that can be kept alive or killed with impunity'. ${ }^{51}$ Through examples of abandonment and by deploying Jean-Luc Nancy's concept of the ban, ${ }^{52}$ Agamben explains how sovereignty is not merely a political or juridical concept, but 'it is the originary structure in which law refers to life and includes it in itself by suspending it'. ${ }^{53}$ These concepts serve the purpose of showing how the law 'applies in no longer applying' ${ }^{54}$ The Roman law

\footnotetext{
49 ibid 6, original emphasis.

50 ibid 9.

${ }^{51}$ Whyte, supra note $42,23$.

52 J Nancy, The Birth to Presence (Stanford University Press, 1993). See also J Nancy, The Gravity of Thought (Humanity Books, 1997).

${ }^{53}$ Agamben (n 1, 1998) 28.

54 ibid.
} 
figure of homo sacer embodies the concept of the ban, as homo sacer finds himself in a zone of indistinction which is both inside and outside of the law, the 'sacred' man, both condemned and/or banned. He can be killed by anybody with impunity as his killing cannot be considered homicide. He cannot however be the object of sacrifice to the gods. ${ }^{55} \mathrm{He}$ is not 'simply set outside the law and made indifferent to it, but rather abandoned by it, that is, exposed and threatened on the threshold in which life and law, outside and inside, become indistinguishable'. ${ }^{56}$ What defines the status of homo sacer, therefore, is not only the same violence to which he finds himself exposed, ${ }^{57}$ captured as he is in the sovereign sphere in which he is vulnerable, ${ }^{58}$ but also the abandonment of the law which enables 'the fostering of life or disallowing it to the point of death' ${ }^{59}$ In the context of EU migration policy, this idea of abandonment is exemplified by the claims that EU-funded interceptions by the Libyan Coast Guards are aimed at rescuing lives at sea, while people intercepted are notoriously returned to detention centres in Libya where they are subjected to torture and other degrading and inhuman treatment. ${ }^{60}$ Similarly, the emergency transfers implemented by the office of the United Nations High Commissioner for Refugees (UNHCR) and by the International Organization for Migration (IOM) since November 2017 reflect this continuous tension between 'fostering life' (e.g. by rescuing the most vulnerable individuals from Libyan detention centres) and 'disallowing it to the point of death' (by transferring them to transit centres in Niger, with no real perspective of resettlement to a permanent country of refuge). ${ }^{61}$

In this context, the concept of the ban developed by Agamben is significant, since it holds together the two symmetrical figures of the sovereign and homo sacer: the ban is what renders the biopolitical abandonment of homo sacer possible, whereby 'the sovereign is the one with respect to whom all men are homines sacri, and homo sacer is the one with respect to whom all men act as sovereigns'. ${ }^{62}$ According to Agamben it is important to understand zoē's exclusion from the political community as a way of capturing it and rendering it political

\footnotetext{
55 ibid 71.

56 ibid 29.

57 ibid 82 .

58 ibid 85.

${ }^{59}$ Foucault, Society Must Be Defended, supra note 21, 254-6. See also Butler and Agamben, supra note 28.

${ }^{60}$ United Nations Office of the High Commissioner for Human Rights (OHCHR) 'Detained and Dehumanised:

Report on Human Rights Abuses against Migrants in Libya’ (13 December 2016) at

<https://reliefweb.int/sites/reliefweb.int/files/resources/DetainedAndDehumanised_en.pdf>.

${ }^{61}$ United Nations High Commissioner for Refugees, 'Flash Update Libya'

<https://reliefweb.int/report/libya/unhcr-flash-update-libya-9-16-november-2017>.

${ }^{62}$ Agamben, supra note 1, 1998, 84.
} 
through this exclusion. In contrast to Foucault, therefore, who sees the emergence of biopolitics when natural life is included in the polis, Agamben sees zoē as being included only through its actual exclusion. ${ }^{63}$ According to Whyte, it is crucial to note 'the ambivalence of abandonment: the one who is abandoned is both utterly exposed to the law and cast outside of its jurisdiction. It is this ambivalence that Agamben reiterates in his account of the sovereign ban. The one who is banned, he writes, is not outside the law in any simple sense, but "exposed and threatened" on the very threshold of the law' ${ }^{64}$ Thus with the term 'inclusive exclusion' Agamben refers to the way in which people are included in the polis by an exclusion which exposes them to violence and death. ${ }^{65}$

Agamben emphasises that since 'the relation of ban has constituted the essential structure of sovereign power from the beginning, ${ }^{66}$ we must now learn to recognise the ban in the political relations that inhabit our times, now that biopolitical power has become more apparent in its various manifestations. The concepts of the ban and of the state of exception are of course closely interlinked, and both are useful to understand the way in which emergency, juridical exclusion/inclusion and violence materialise themselves in various contemporary contexts, including within the infrastructures of EU's liquid borders. These concepts are also the theoretical key to understanding the relationship between law and anomy - that is law and the absence of law. According to Agamben, the state of exception is 'a void, a blank and this empty space is constitutive of the legal system'. ${ }^{67}$ States, Agamben argues, do not intervene to effectively prevent catastrophes, they allow them to happen (and in some cases even contribute to their occurrence), so that they can then use them to intervene and restore security in the right way, 'to orientate them in a profitable direction'. ${ }^{68}$ The examples of the interceptions at sea by the Libyan Coast Guard and of the UNHCR-IOM emergency transfers to Niger fully encapsulate this idea of neglecting and/or contributing to the occurrence of catastrophes, to set the stage for a 'profitable intervention' which redirects refugees away from Europe and towards the Sahel.

Situations of crisis, security threats and dangers, according to Agamben, are therefore

\footnotetext{
${ }^{63}$ Whyte, supra note $42,29-30$.

64 ibid, 29.

65 ibid.

${ }^{66}$ Agamben, supra note 1, 1998, 111.

${ }^{67}$ Raulff, supra note 30, 609.

68 ibid 611.
} 
presented and perceived as omnipresent and are internalised to become part of the sovereign's technique of governing, of its biopolitics. The state of exception, in other words, has now become the prevailing paradigm, the nomos of modernity, the technical norm of government. Yet, what does this technique consists of? Returning to the ban and to the concept of abandonment, within the context of the European Agenda it is possible to see how biopolitical power operates not only to save and manage the life and movement of refugees, but also to 'foster life or disallow it to the point of death'. ${ }^{69}$ As outlined above, this conceptualisation elaborates on Foucault's argument that the sovereign right to 'take life or let live' has transformed itself into the power 'to make live and let die'. In Agamben's and Butler's understanding of this exercise of biopower, there is no explicit decision announcing those who must die, but the emergence of systematic forms of deliberate neglect. ${ }^{70}$ Across the Mediterranean, the 'fostering of life or disallowing it to the point of death' is exemplified in the way in which the lines between rescue operations and push-back/pull-back ${ }^{71}$ policies have become increasingly blurred: refugees are first (sometimes, but not always) ${ }^{72}$ rescued from death by drowning, only to be then relegated to the detention centres in Libya, or the hotspots in Italy/Greece, or similarly abandoned in zones of indeterminacy and indistinction which are regularly populated by humanitarian non-governmental organisations, private security contractors and the state security apparatus.

'The Jungle' camp in the French city of Calais is another classic example of this abandonment, and of the manifestation of a zone of indeterminacy and indistinction. ${ }^{73}$ Out of the many camps to have appeared around Calais since 1999, 'The Jungle' by April 2015 was inhabited by more than 1,000 people wishing to cross the Channel to the UK. ${ }^{74}$ With no comprehensive measures

\footnotetext{
${ }^{69}$ Butler and Agamben, supra note 28

${ }^{70} \mathrm{I}$ am indebted to Professor Dino Kritsiotis for observing how this new exercise of biopolitical power appears more prone to being used with soft(er) targets, e.g. refugees, the poor and vulnerable, etc.

${ }^{71}$ N Markard, 'Right to Leave by Sea: Legal Limits on EU Migration Control by Third Countries' (2016) 27 European Journal of International Law 591, 594-7.

${ }^{72}$ See for instance the notorious 'left to die incident' of March 2011, in which 61 people died off the coast of Libya, after being at sea for sixteen days and allegedly being ignored by NATO warships part of Operation Unified Protector. This 'incident' is examined in Papastavridis, supra note 13, together with the example of the sinking of a boat with 500 people off the coast of Lampedusa on 3 October 2013. In the latter situation, approximately 360 died despite the intervention of the Italian Coastguard which rescued 155 people. See further J Coppens, 'The Lampedusa Disaster: How to Prevent Further Loss of Life at Sea?' (2013) 7 International Journal on Marine Navigation and Safety of Sea Transportation 589.

${ }^{73}$ On the reality and political dynamics of 'The Jungle', see H Schwenken, 'From Sangatte to "The Jungle": Europe's Contested Borderlands' in H Schwenken and S Ruß-Sattar (eds), New Border and Citizenship Politics (2014)

${ }^{74}$ A Chrisafis, 'At night it's like a horror movie - inside Calais' official shantytown' The Guardian, 6 April 2015, available at www.theguardian.com/world/2015/apr/06/at-night-its-like-a-horror-movie-inside-calaiss-officialshanty-town.
} 
in place to ensure that its inhabitants (including unaccompanied children) were properly housed or relocated, ${ }^{75}$ 'The Jungle' was demolished in October 2016 by the French authorities. Emblematically, however, the indeterminacy of 'The Jungle' continues to endure: in March 2017 the Mayor of Calais issued a ban prohibiting charitable organisations from distributing food to refugees in the industrial area where the camp was located. The decision was justified by a claim that the distribution of meals represented 'a threat to peace and security in the area' ${ }^{76}$ On 31 July 2017, the Conseil d'Etat, France's highest administrative court, ruled that the French government must, inter alia, provide refugees living in the municipality of Calais with drinking water, showers and sanitation facilities. ${ }^{77}$ As of October 2017, however, over 700 refugees were reported as still living in Calais without shelter and in dire conditions. ${ }^{78}$

The language of humanitarianism was also deployed to justify the relocation of children from 'The Jungle' to the United Kingdom (UK). At the time of the demolition of 'The Jungle', many of the unaccompanied children living in the camp were waiting relocation to the UK by virtue of the passing of the Dubs amendment (titled 'Unaccompanied Refugee Children: Relocation and Support') to the Immigration Bill 2016. In May 2016 the Dubs amendment became section 67 of the Immigration Act 2016, which establishes that 'The Secretary of State must, as soon as possible after the passing of this Act, make arrangements to relocate to the United Kingdom and support a specified number of unaccompanied children from other countries in Europe'. In February 2017 the government announced that the 'specified number' accepted under the Dubs amendment was to be 350 , a figure later revised to $480 .{ }^{79}$ Shortly afterwards, however, and after only 200 children had been brought to the UK, the Dubs relocation scheme was suspended: former Home Secretary, Amber Rudd, suggested that the scheme was attracting

\footnotetext{
${ }^{75}$ See C Moseley, 'Demolishing the Calais camp has just made refugees' lives harder' The Guardian, 3 March 2017, available at https://www.theguardian.com/commentisfree/2017/mar/03/calais-refugee-camp-ban-foodhandouts.

${ }^{76}$ L Pasha-Robinson, 'Mayor of Calais bans distribution of food to migrants', The Independent, 2 March 2017, available at http://www.independent.co.uk/news/world/europe/calais-mayor-natacha-bouchart-jungle-refugeecamp-ban-food-distribution-migrants-a7608676.html; see also M Bulman, 'Charities vow to continue giving food to refugees despite Calais Mayor's ban' The Independent, 3 March 2017, available at http://www.independent.co.uk/news/world/europe/calais-refugees-food-ban-charities-to-continue-distributiondespite-mayor-a7610321.html.

77 Conseil d'État, 31 juillet 2017, Commune de Calais, Ministre d'État, ministre de l'Intérieur, Nos 412125, 412171, available at http://www.conseil-etat.fr/Decisions-Avis-Publications/Decisions/Selection-des-decisionsfaisant-1-objet-d-une-communication-particuliere/Conseil-d-Etat-31-juillet-2017-Commune-de-Calais-Ministred-Etat-ministre-de-1-Interieur.

${ }^{78}$ Mark Townsend, 'French police "use beatings, tear gas and confiscation" against Calais refugees', 29 October 2017, available at https://www.theguardian.com/world/2017/oct/29/calais-child-refugees-police-beatingsharassment.

${ }^{79}$ See UK House of Commons, 'Calais and Unaccompanied Child Refugees in Europe', Debate Pack No CDP2017-0208, 31 October 2017.
} 
children and risked incentivising them 'making perilous journeys across Europe'. ${ }^{80}$

The emergency discourse and the language of humanitarianism exemplified above through the example of 'The Jungle' and of the Dubs amendment operate to delineate a situation of protracted 'crisis', thus justifying a state of exception where the meaning of the laws guaranteeing international protection is hollowed out. As mentioned above, this image of 'crisis' is consolidated and maintained by the framing of people trying to reach the EU as a security threat and of the migration movement itself as precipitating an unprecedented humanitarian emergency. The responses that can be envisaged to respond to this emergency pertain, by nature therefore, to the realm of exception where more profound questions on the structural nature of the problem at hand are automatically bypassed. ${ }^{81}$ Since an 'emergency' demands immediate action, there can be no time for further analysis, conceptualisation, identification of longer-term solutions, or for governance through law. With the normalisation of the state of exception, the administration of anomy and of the absence of order is also normalised: domestic, regional and international law which would normally operate to ensure that refugees have access to international protection are thus, it would seem, irrevocably compromised. ${ }^{82}$ Although the law continues to exist in the background, it becomes merely management tool-focused as it is on figures and statistical data. Thus, through the administration of humanitarian assistance the lives of refugees are stabilised, managed and controlled by sovereign power through comprehensive systems of administration and control. Simultaneously, however, sovereign power also 'disallows the lives of refugees to the point of death': ${ }^{83}$ EU officials and spokespersons of EU member states continue to appropriate the language of humanitarianism in order to present their measures as urgent and indeed indispensable to save the lives of refugees and to prevent them from embarking on perilous journeys or from falling in the hands of human traffickers. Yet, as I will discuss further in part

\footnotetext{
${ }^{80}$ E Addley, 'Why has the UK ended its "Dubs" child refugee scheme?' The Guardian, 10 February 2017, available at https://www.theguardian.com/uk-news/2017/feb/10/why-has-the-uk-ended-its-dubs-child-refugeescheme.

${ }^{81}$ P Pallister-Wilkins, 'Interrogating the Mediterranean Migration Crisis' (2016) 21 Mediterranean Politics 311.

${ }^{82}$ Similarly, see Charlesworth, supra note 3, at 388-90, where she discusses the silences resulting from this 'crisis' framing in international law.

${ }^{83}$ In order to explain how the sovereign power establishes what must live and what must die, Foucault discusses the ways in which biopolitics instrumentalises the idea of killing by introducing the idea of racism, through which killing becomes 'tolerable': 'When I say killing I obviously do not mean simply murder as such, but also every form of indirect murder: the fact of exposing someone to death, increasing the risk of death for some people, or, quite simply, political death, expulsion, rejection, and so on'. See Foucault, Society Must Be Defended, supra note $21,254-6$.
} 
II, sovereign power also acquires a more distinctly lethal dimension in the multifarious manifestations of the camp inherent to the systems of border governance instituted by EU. ${ }^{84}$

\section{The Physical and Legal Embodiments of the State of Exception}

In this part I examine the spatial transformation resulting from the measures adopted to implement the European Agenda and I describe the non-linear emergence of the camp, understood by Agamben as a paradigmatic space, 'the structure in which the state of exception is permanently realized'. ${ }^{85}$ The physical manifestations of the camp span from the hotspots in Italy and Greece to the detention centres and processing hubs scattered throughout North Africa and the Sahel. ${ }^{86}$ In parallel we also see the emergence of borderline legal manifestations of the camp - which I call the legal infrastructures or apparatus of the EU's liquid borders. As I discuss below the EU's exploitation of the concept of 'safe third country', ${ }^{87}$ its idea of 'refugee protection elsewhere ${ }^{88}$ and the reliance on formal or informal readmission agreements with non-EU countries of transit or origin ${ }^{89}$ can all be seen as elements of the contemporary apparatus (dispositif) of EU power. As explained by Agamben, Foucault first defined the term dispositif in 1977 as

first and foremost, a thoroughly heterogeneous set consisting of discourses, institutions, architectural forms, regulatory decisions, laws, administrative measures, scientific statements, philosophical, moral and philanthropic propositions - in short, the said as much as the unsaid. Such are the elements of the apparatus. The apparatus itself is the network that can be established between these elements. (...) I said that the nature of an apparatus is essentially strategic, which means that we are speaking about a certain manipulation of relations of forces, either as to develop them in a particular direction, or to block them, to stabilize them, and to utilize them. The apparatus is thus always inscribed into a play of

\footnotetext{
${ }^{84}$ Vaughan-Williams aptly describes the lethal dimension of biopolitical EU border governance and, following Agamben's discussion of thanatopolitics, calls the EU borders 'thanatopolitical borders'. See Vaughan-Williams, supra note 4, chapter 3.

${ }^{85}$ G Agamben, Means Without End: Notes on Politics: What is a Camp? (University of Minnesota Press, 2000) at 40 .

${ }^{86}$ F Molenaar and F El Kamouni-Janssen, 'Turning the Tide: The Politics of Irregular Migration in the Sahel and Libya' CRU Report, February 2017, Netherland Institute of International Relations/Clingendael, available at www.clingendael.nl/publication/turning-tide.

87 See European Council on Refugees and Exiles/ECRE, 'Debunking the "Safe Third Country" Myth' (October 2017), available at https://www.ecre.org/wp-content/uploads/2017/11/Policy-Note-08.pdf. See also M Gil-Bazo, 'The Safe Third Country Concept in International Agreements on Refugee Protection: Assessing State Practice' (2015) 33 Netherlands Quarterly of Human Rights 42.

${ }^{88}$ See M Foster, 'Protection Elsewhere: The Legal Implications of Requiring Refugees to Seek Protection in Another State' (2007) 28 Michigan Journal of International Law 223. See also S Taylor, 'Protection Elsewhere/Nowhere' (2006) 18 International Journal of Refugee Law 283.

${ }^{89}$ JP Cassarino, 'Informalizing EU Readmission Policy' in A Ripoll Servent and F Trauner (eds) The Routledge Handbook for Justice and Home Affairs Research (Routledge, 2018 - chapter copy on file with author).
} 
power, but it is also always linked to certain limits of knowledge that arise from it and, to an equal degree, condition it. The apparatus is precisely this: a set of strategies of the relations of forces supporting, and supported by, certain types of knowledge. ${ }^{90}$

Expanding on Foucault's definition, Agamben defines the dispositif as

literally anything that has in some way the capacity to capture, orient, determine, intercept, model, control, or secure the gestures, behaviors, opinions, or discourses of living beings. Not only, therefore, prisons, madhouses, the panopticon, schools, confession, factories, disciplines, juridical measures, and so forth (whose connection with power is in a certain sense evident), but also the pen, writing, literature, philosophy, agriculture, cigarettes, navigations, computers, cellular telephones and - why not-language itself, which is perhaps the most ancient of apparatuses. $^{91}$

Thus, in the same way in which the language of humanitarianism has been appropriated to present as acceptable the deliberate exposure of refugees to death, ${ }^{92}$ there are also other less obvious techniques of sovereign power that operate in similar ways to materialise the state of exception. According to Agamben, the camp is a signifier, a space 'topologically different from a simple space of confinement', ${ }^{93}$ where 'bare life and juridical rule enter into a threshold of indistinction'. ${ }^{94}$ Following from this, 'we must admit that we find ourselves virtually in the presence of a camp every time such a structure is created, independent of the crime that are committed there and whatever its denomination and specific topography'. ${ }^{95}$ Through this lens Agamben is able to recognise a camp every time that a seemingly innocuous place is used as a space 'in which the normal order is de facto suspended and in which whether or not atrocities are committed depends not on law but on the civility and ethical sense of the police who temporarily act as sovereign'. ${ }^{96}$

\footnotetext{
${ }^{90}$ M Foucault, Power/Knowledge: Selected Interviews and Other Writings, 1972-1977 (Pantheon Books, 1980) at $194-6$.

${ }^{91}$ See G Agamben, What is an Apparatus? and Other Essays (Stanford University Press, 2009) at 14.

${ }^{92}$ Polly Pallister-Wilkins argues that humanitarian intervention is used to 'mask the violence of the border' and also to offer an alternative, more positive narrative to the increased militarisation of border practices. In her view the appropriation of humanitarian language also masks the overlap between rescue operation and capture/border policing missions. Through this masking process border violence is thus erased and neutralised, together with any counter-narrative attempting to expose it. See P Pallister-Wilkins, 'Humanitarian Rescue/Sovereign Capture and the Policing of Possible Responses to Violent Borders' (2017) 8 Global Policy 19.

93 Agamben, supra note 1 (1998) at 28.

94 Agamben, supra note 22, at 171-2.

${ }^{95}$ Agamben, supra note 1 (1998) at 174.

${ }^{96}$ Such as when in 1991 the Italian police herded Albanian immigrants in the stadium in Bari before forcibly returning them. Ibid.
} 
International law, I argue, plays a key role in enabling and maintaining the existence of various manifestations of the state of exception, and thus of the camp. In what follows I examine Agamben's paradigm of the camp and how it manifests itself in the current policies of the European Agenda.

\section{A. The Camp and its Manifestations Along the EU's Liquid Borders}

In order to comprehend the ineffable nature of the camp and its juridico-political structure, it is necessary to look at what Agamben calls the 'constitutive nexus' between the state of exception and the camp. When the law that underpins the state of exception becomes normalised, when it becomes the rule (such as in the example of the Schutzhaft, the Nazi decree that confirmed the suspension of all rights but did not directly refer to a previously declared state of exception), ${ }^{97}$ a space opens up for the camp to delineate itself. Thus, if we understand the camp as a result of the state of exception rather than of ordinary law, it cannot be conceived as an unintentional anomaly confined to a very specific set of historical circumstances. Rather than confuse the camp with the legal rules that confirmed its existence, we should conceive of it as 'the hidden matrix and nomos of the political space in which we are still living'. ${ }^{98}$ To explain this conceptual shift, Agamben recounts how during the Nazi regime, the jurist Werner Spohr approvingly referred to the concept of a 'state of willed exception' (or gewollten Ausnahmezustand). This terminology clearly indicates that the state of exception is not determined by 'an external and provisional state of factual danger' ${ }^{99}$ or by an 'extrapolitical, natural fact that law must limit itself to confirming and recognizing. It is, rather, a threshold in which law constantly passes over into fact and fact into law, and in which the two planes become indistinguishable'. ${ }^{100}$ The bare life into which the people entrapped in the camp are transformed is born out of an inherently political decision which cannot be subsumed to a matter of fact (a quaestio facti) nor to a matter of law (a quaestio iuris): what underpins the camp is a fundamentally biopolitical technique of government which collapses fact into law, creating a situation of absolute indistinction between the two. ${ }^{101}$

It is within this paradox of a state of willed exception that I wish to locate the border practices that the EU and its member states deploy in their relentless implementation of the European

\footnotetext{
97 ibid 169.

98 ibid 166.

99 ibid 168.

100 ibid 171 .

101 ibid.
} 
Agenda. These practices, as we have seen above, thrive on the appropriation of a humanitarian language which mask the increasing militarisation, privatisation and externalisation of migration control. ${ }^{102}$ Although these phenomena are not new, they are now significantly accelerated and exacerbated by the willed biopolitical technique of government deployed by the EU and its member states. In the remainder of this article I focus on two recent developments in EU migration policies which, I believe, can be considered as apparent manifestations of the camp. They encompass both the physical and legal elements of it: one pertains the 'safe return' system built around the concept of 'safe third countries' - whereby refugees can be sent back to their country of origin or to a third country through which they have transited, because they are considered 'safe'; and the other is the proliferation of cooperation agreements on migration management and readmission with third countries of origin and destination-with the resultant blurring of the lines between voluntary and involuntary returns. It is important to note that these two phenomena are indeed interlinked. The EU return policy, in particular, complements and consolidates a predominant tendency to fast-track the processing and forced return of people who were not immediately deemed entitled, for various reasons, to international protection. Fast-tracking procedures have been criticised for over a decade, since with their objective of speeding up the refugee determination process, they often result in decisions that do not reflect the real nature of the asylum cases considered and in turn precipitate the repatriation of people to places where they are at risk of persecution. ${ }^{103}$

More specifically, the establishment of the return policy reflects the preoccupation of the EU with a phenomenon called 'secondary movement', that is the movement of refugees from one member state, in which they do not want to stay, to another in which they intend to apply for asylum. The return policy relies on the immediate identification, registration and fingerprinting of refugees in dedicated processing centres in hotspots in Greece and Italy, in order to ensure their subsequent relocation to other EU member states or return to a safe third country. This system is in turn made possible by a network of agreements with third countries which have been 'persuaded' - mainly through a 'more for more' approach which makes the disbursement of development aid conditional on cooperation on migration ${ }^{104}$ - to promptly accept back

\footnotetext{
102 Vaughan-Williams, supra note 4, at 20.

${ }^{103}$ L Kirk, 'Accelerated Asylum Procedures in the United Kingdom and Australia: 'Fast Track' to Refoulement?' in M O'Sullivan and D Stevens (eds), States, the Law and Access to Refugee Protection: Fortress and Fairness (Hart Publishing, 2017) at 243.

${ }^{104}$ Davitti and La Chimia, supra note 12.
} 
returnees. ${ }^{105}$ These practices, in my view, also presents us with disturbing examples of how transitional rules become normalised and transform themselves into a state of exception. These policies were initially envisaged as part of a set of provisional measures on international protection, tabled in May 2015 by the Council of the European Union (Council) in an initial proposal for a Relocation Decision. ${ }^{106}$ Their aim was to 'support' the frontline member states of Greece and Italy which, by then, were experiencing a marked increase in the number of refugees' arrivals. ${ }^{107}$ These measures were subsequently adopted in September 2015 through two Relocation Decisions: the first one on 14 September, ${ }^{108}$ establishing the relocation of 40,000 people from the Greek and Italian hotspots to other EU member states; and the second one on 22 September $2015,{ }^{109}$ raising the number of people to be relocated to 160,000 (an additional 120,000). An amending third Decision was then adopted on 29 September 2016, ${ }^{110}$ to specifically provide for the direct relocation of refugees from Turkey, following the readmission 'deal' between EU and Turkey that I discuss below.

105 Clear examples of these cooperation agreements on migration management, often going well beyond readmission, are the controversial 2017 Memorandum of Understanding between Italy and Libya, the 2016 EUAfghanistan Joint Way Forward and the 2016 Memorandum of Understanding between the Italian and Sudanese police services. On Libya, see A Palm, 'The Italy-Libya Memorandum of Understanding: The Baseline of a Policy Approach Aimed at Closing All Doors to Europe?' (2 October 2017) EU Immigration and Asylum Law and Policy Blog, available at http://eumigrationlawblog.eu/the-italy-libya-memorandum-of-understanding-the-baseline-ofa-policy-approach-aimed-at-closing-all-doors-to-europe/. On Afghanistan, see full text of 'Joint Way Forward on migration issues between Afghanistan and the EU', available at https://reliefweb.int/report/afghanistan/joint-wayforward-migration-issues-between-afghanistan-and-eu; see also Amnesty International, 'Forced Back to Danger: Asylum-Seekers Returned from Europe to Afghanistan' (5 October 2017), available at https://www.amnesty.org/en/documents/asa11/6866/2017/en/. On Sudan, see full text of the Italy-Sudan agreement, available at https://www.asgi.it/wp-content/uploads/2016/10/accordo-polizia-Italia-Sudan_rev.pdf. See also B Borletto et al, 'Memorandum of Understanding between Italy and Sudan: A Legal Analysis' (Human Rights and Migration Law Clinic of Turin, 2017), available at https://www.asgi.it/wpcontent/uploads/2017/10/Report-Memorandum-of-Understanding-Sudan-Italy-SL-Clinic-UniTO.pdf.

${ }^{106} \mathrm{COM}(2015)$ 286, 27 May 2015.

107 The specific objective of the two Relocation decisions of September 2015, infra notes 108 and 109, was to manage the arrival of asylum seekers in Greece, Italy and Hungary, but then Hungary refused to be considered a 'frontline' member state and was eventually excluded from the hotspot system. Note however that the EU obsession with the increasing number of people arriving across the Mediterranean during the first half of 2015 masked the fact that these arrivals, although markedly higher compared to the previous year, would have not represented an impossible relocation challenge, if the EU response had been based on solidarity. See E Guild, C Costello and V Moreno-Lax, 'Implementation of the 2015 Council Decisions establishing provisional measures in the area of international protection for the benefit of Italy and Greece' (March 2017) Study for the European Parliament's Policy Department for Citizen's Rights and Constitutional Affairs at the request of the LIBE Committee, available www.europarl.europa.eu/RegData/etudes/STUD/2017/583132/IPOL_STU(2017)583132_EN.pdf, at 17-18.

108 Council Decision (EU) 2015/1523 of 14 September 2015 establishing provisional measures in the area of international protection for the benefit of Italy and of Greece.

109 Council Decision (EU) 2015/1601 of 22 September 2015 establishing provisional measures in the area of international protection for the benefit of Italy and Greece.

${ }^{110}$ Council Decision (EU) 2016/1754 of 29 September 2016 amending Decision (EU) 2015/1601 establishing provisional measures in the area of international protection for the benefit of Italy and Greece. 
By December 2016, however, the Decisions had resulted in only 11,966 actual relocations out of the total figure of 160,000 foreseen, mainly because of the refusal by some EU member states to accept, either totally or partially, the relocation of refugees from the hotspots. ${ }^{111}$ The failed implementation of the Relocation Decisions is mainly due to a lack of political willingness from the member states; a lack of capacity to process large volumes of asylum applications, especially in relation to unaccompanied children and other vulnerable people; and a widespread perception that refugees represent a threat to security and public health. ${ }^{112}$ This security discourse fully reflects the 'crisis' framing enshrined in EU migration policies, and is further compounded by an additional discriminatory and racist dimension pushed by the Visegrád group (or V4, i.e. the Czech Republic, Hungary, Slovakia and Poland), which vehemently opposes the relocation of refugees from predominantly Muslim countries. ${ }^{113}$

This refusal to relocate refugees is accompanied by other anti-immigration measures, which exemplify the state of willed exception underpinning EU migration policies and reproduce the paradigm of the camp. These measures aim to further deter refugees' attempts to reach the EU and in turn accelerate forced returns to third countries of origin and transit. At the end of March 2017, for instance, the Hungarian Prime Minister, Viktor Orban, announced that 324 shipping containers had been installed in two camps near the transit zones of Tompa and Röszke on the Serbian-Hungarian border, for the automatic detention of all asylum seekers, including those already housed in refugee reception centres across Hungary. This detention measure was approved by the Hungarian Parliament on 7 March 2017 through an amendment of the Hungarian Asylum Act which envisages the return of all asylum seekers (including families and unaccompanied children between 14 and 18) to two transit zones of the Hungarian-Serbian border, and their detention in the camps located on the Serbian side of the razor-wire fence between the two states. ${ }^{114}$ This measure is part of a series of amendments to the Hungarian Asylum Law, aimed at increasingly curtailing access to international protection in Hungary. ${ }^{115}$

\footnotetext{
${ }^{111}$ Implementation of the 2015 Council Decisions, supra note 107, chapter 2 'Relocation in practice', outlining how Austria, Hungary and Poland have failed to comply with the Relocation Decisions, despite their legally binding nature, while other countries have made slow process in relocating refugees, whilst still refusing some on public security and public health grounds.

112 ibid 29-35.

113 ibid.

${ }^{114}$ European Council on Refugees and Exiles/ECRE, 'Hungary: Latest amendments legalise extrajudicial pushback of asylum-seekers' (7 July 2016), available at www.ecre.org/hungary-latest-amendments-legaliseextrajudicial-push-back-of-asylum-seekers/.

${ }^{115}$ See Human Rights Watch, 'Hungary: Draft Law Tramples Asylum Seekers' Rights', 7 March 2017, available at https://www.hrw.org/news/2017/03/07/hungary-draft-law-tramples-asylum-seekers-rights.
} 
The Hungarian government's hard-line approach to refugees should be understood in the context of its long-standing refusal to offer international protection except in cases based on claims for political asylum, which in their interpretation should only amount to approximately $1 \%$ of the asylum requests submitted. ${ }^{116}$ In response to the European Agenda, in early 2016 Hungary closed its Southern border with Serbia, thus sealing the 'Balkan route', which at the time was the main passage through which refugees moved from Greece to northern Europe. ${ }^{117}$ Since July 2015 Hungary has also identified neighbouring Serbia as a safe country of transit, ${ }^{118}$ despite the country having been officially declared unsafe by the UN Office of the High Commissioner for Refugees (UNHCR) in 2012, ${ }^{119}$ and then again in $2016 .{ }^{120}$ This move by Hungary de facto enabled the return to Serbia of any asylum seekers transiting through this neighbouring country, based on the fact that they should have availed themselves of the opportunity to apply for asylum there, Serbia being considered 'safe'.

This approach has been rejected by the European Court of Human Rights (ECtHR) in its decision in the Ilias and Ahmed $v$ Hungary ${ }^{121}$ case of 14 March 2017, where the court found that the return to Serbia in 2015 of two Bangladeshi asylum seekers under the Hungarian fasttrack asylum procedure was in breach of articles 3 and 5 of the European Convention of Human Rights (ECHR), since the refugees had been unlawfully deprived of their liberty and kept in detention conditions which were inhumane and degrading. Furthermore, Hungary's consideration of Serbia as a safe third country resulted in refugees not having access to an effective remedy to challenge the return decision, in breach of Article 13 ECHR (right to an effective remedy). The decision by the Hungarian authorities, in fact, had been made exclusively on the basis of the domestic legislation declaring Serbia a safe third country, without a thorough consideration of the individual risk on return to Serbia and of the submitted reports of degrading and inhumane treatment of refugees already there. The ECtHR's decision,

\footnotetext{
116 ibid.

117 'One Year from the EU-Turkey Deal', supra note 13, at 5.

118 See Hungarian Government, 'Government has identified list of safe countries', Press Release of 22 July 2015 , available at www.kormany.hu/en/news/government-has-identified-list-of-safe-countries.

${ }^{119}$ UNHCR, 'Note on Dublin Transfers to Hungary of People Who Have Transited Serbia - Update', December 2012, available at www.refworld.org/docid/507298a22.html.

${ }^{120}$ UNHCR, 'Hungary as a Country of Asylum. Observations on Restrictive Legal Measures and Subsequent Practices Implemented Between July 2015 and March 2016', May 2016, available at http://www.refworld.org/docid/57319d514.html.

${ }^{121}$ European Court of Human Rights, Ilias and Ahmed v Hungary, Application no 47287/15 (14 March 2017), available at http://hudoc.echr.coe.int/eng\#\{"itemid":["001-172091"]\}.
} 
however, was effectively ignored by the Hungarian government, ${ }^{122}$ which two weeks after the judgment proceeded to announce that the shipping containers installed near the transit zones on the Serbian-Hungarian border were officially open. ${ }^{123}$

The systematic and increasing reliance on formal or informal readmission agreements, signed through political and cooperation 'compacts' with third countries of origin and return is a further aspect of the immigration measures being replicated across and beyond the EU, and which reproduces the Agambian paradigm of the camp. The EU-Turkey 'deal' is only one of the many compacts - another biopolitical technique of bordering governance-according to which asylum seekers who have reached Greece from Turkey and who have been found to have no ground for international protection can be automatically returned to Turkey because of its safe third country designation. One of the key points of the 'deal' was its prioritisation of Syrian refugees, since for every Syrian returned to Turkey, another Syrian was meant to be resettled directly from Turkey to an EU member state. This one-to-one swap envisaged a cap of 72,000 resettlements, in line with the third Relocation Decision of September $2016,{ }^{124}$ and substantively relied on the effective functioning of the Greek hotspots. Despite the lack of compliance of most EU member states with the Relocation Decisions, already discussed above, the EU-Turkey 'deal' is vaunted by the European Commission as a success in stemming the flows across the Aegean route, improving return rates and preventing refugees from putting their lives at risk. ${ }^{125}$

Simultaneously, the EU-Turkey 'deal' is also being presented as a benchmark to be replicated

\footnotetext{
${ }^{122}$ See Hungarian Government, 'Border protection agencies fully prepared for entry into force of reinforced legal border closure', Press Release of 27 March 2017, available at www.kormany.hu/en/ministry-ofinterior/news/border-protection-agencies-fully-prepared-for-entry-into-force-of-reinforced-legal-border-closure.

${ }^{123}$ For clarification, I am not herewith arguing that a bolstering of the rule of law could provide an answer to the structures identified by Agamben, nor I consider Hungary an isolated case within the EU. As argued in this article, the violent effects of EU migration policies are not accidental, but inherent to the deterrent measures adopted by the EU and its member states. See further Whyte, supra note 42 , at 6 , where she discusses how Agamben himself sees certain categories of Western politics, including the rule of law, as unable to provide appropriate answers to the manifestations of biopower.

${ }^{124}$ Relocation Decision on 29 September 2016, supra note 110. The swap entailed the promise of the disbursement of three billion euros to the Facility for Refugees in Turkey, of an agreement on visa liberalisation for Turkish citizens and the speeding up of negotiations for Turkey's accession to the EU. All of the above, however, was made conditional on ensuring prompt returns to Turkey and the stemming of any new arrival to Greece.

${ }^{125}$ See e.g. European Commission, 'Fourth Report on the progress made in the implementation of the EU-Turkey Statement' (8 December 2016) EU Doc COM(2016) 792 final.
} 
elsewhere, ${ }^{126}$ with Italy and Germany ${ }^{127}$ pushing for the implementation of other 'compacts' under the so-called Migration Partnership Framework (MPF), ${ }^{128}$ endorsed in June 2016 by the European Council. In light of the MPF and similar frameworks such as the Khartoum process, cooperation agreements continue to be negotiated and concluded by the EU itself or by its member states with various key countries, including Afghanistan, Libya, Niger, Nigeria, Senegal, Sudan, Mali, Tunisia, Morocco and Ethiopia. ${ }^{129}$ In the meantime, after the 'successful' sealing of the Aegean and Balkan routes described above, the focus has shifted towards closing the Central Mediterranean route (through Libya and Italy), with measures heralded by a Joint Communication entitled 'Migration on the Central Mediterranean Route: Managing Flows, Saving Lives'. ${ }^{130}$ Amongst these measures there is the allocation of 200 million euros in 2017 for migration-related projects aimed, inter alia, at the 'humanitarian' repatriation of refugees to Libya, with an initial target of 5000 returns. ${ }^{131}$

There is no doubt that the EU humanitarian cum security discourses outlined above mask the abysmal conditions to which refugees are exposed as part of these systems of processing, detention and return. I submit however that these conditions cannot be seen as accidental, noras it is often discussed-as the result of dysfunctional bureaucracies and of the inherent challenges posed by situations of mass influx. ${ }^{132}$ Such interpretations would contribute to the perception that external matters of fact ${ }^{133}$ (e.g. the inefficient implementation by Greece or the unprecedented numbers of refugees reaching the EU) or matters of law (e.g. the inapplicability of international protection provisions to refugees who should have applied for asylum

\footnotetext{
${ }^{126}$ See e.g. European Commission, 'Third Progress Report on the Partnership Framework with third countries under the European Agenda on Migration '(2 March 2017) EU Doc COM(2017) 205 final.

${ }^{127}$ See the non-paper submitted by the Italian government in May 2016: 'Migration Compact: Contribution to an EU Strategy for External Action on Migration' (2016), available at www.governo.it/sites/governo.it/files/immigrazione_0.pdf. See also Italy-Sudan Memorandum of Understanding on migration (MoU), supra note 90. For allegations that aid funds linked to this MoU might support the Janjaweed militia, see www.statewatch.org/news/2016/oct/ep-meps-letter-collective-expulsions-to-Sudan.pdf. In relation to Germany, see also the pressure exerted by German officials on the Egyptian and Tunisian governments, and the German proposal to set up off-shore detention and processing centres in Tunisia: G Baczynska, 'EU pushes migration talks with Tunisia, Egypt' Reuters, 20 February 2017, available at http://uk.reuters.com/article/ukeurope-migration-egypt-tunisia-idUKKBN15Z19L.

${ }^{128}$ European Commission, 'Communication on establishing a new Partnership Framework with third countries under the European Agenda on Migration' (7 June 2016) EU Doc COM92016) 385 final.

${ }^{129}$ Third Progress Report, supra note 126, at 3-10.

${ }^{130}$ EU Doc JOIN(2017) 4 final of 25 January 2017.

${ }^{131}$ Third Progress Report, supra note 126, at 12-13. These 200 million euros are additional to the 200 million euros allocated by Italy to implement the Italy-Libya MoU, supra note 93.

${ }^{132}$ See e.g. European Commission, 'Eight Report on Relocation and Resettlement' (8 December 2016) EU Doc $\operatorname{COM}(2016) 791$ final.

${ }^{133}$ Agamben, supra note 1 (1998), at 168 and 171.
} 
elsewhere $)^{134}$ are the cause of the physical and mental harm to which refugees are exposed, their lives systematically 'disallowed to the point of death' ${ }^{135}$ Furthermore, by accepting and discussing this situation as accidentally caused, we would divert our attention from the need to understand that it is actually intrinsic to the enhanced deterrent measures adopted by the EU and its member states as part of the European Agenda. Most importantly, this systemic negligence towards refugees is an integral element of the EU's sovereign technique of governing, deployed in full force to maintain a willed state of exception and the biopolitical abandonment of these people.

\section{Reflections and Conclusion}

In this article I have engaged with Agamben's work in order to challenge the current policies of the European Agenda, and more specifically the 'crisis' framing and the way in which EU officials have appropriated the humanitarian discourse to justify the adoption of draconian exceptional measures to stem the flow of refugees towards the EU. I have used Agamben's paradigm of the camp, and his conceptualisation of the ban and of the state of exception to present my central argument that this posture of humanitarianism adopted by the EU masks the fact that the appalling situation in which refugees are abandoned is not accidental. It must be understood as a form of systemic negligence towards refugees and as a constitutive biopolitical strategy of the measures adopted by the EU and its member states as part of the European Agenda. This analysis neutralises EU claims that these enhanced deterrent measures are aimed at saving lives at sea, and in turn opens up an opportunity for their rejection and reversal.

Admittedly, the picture that I have outlined so far does not leave much space for imagining how this state of willed exception could be reversed, and Agamben himself claims that certain categories of Western politics are bankrupt and exhausted (e.g. sovereignty, citizenship, the rule of law and, crucially, human rights). However, he 'sees this exhaustion as the condition of the possibility of a new politics', ${ }^{136}$ and his work has been conceptualized and used in different ways by various scholars, beyond the initial paralysis that an Agambian analysis may instil. ${ }^{137}$ In Whyte's view, it is necessary to build on the strengths of Agamben's work to 'invent new

\footnotetext{
${ }^{134}$ See Foster, supra note 88.

${ }^{135}$ Butler and Agamben, supra note 28.

${ }^{136}$ Whyte, supra note $42,6$.

${ }^{137}$ See e.g. J Butler, Precarious Life: The Powers of Mourning and Violence (Verso, 2004), 61. See also J Reid, 'The Biopoliticization of Humanitarianism: From Saving Bare Life to Securing the Biohuman in PostInterventionary Societies' (2010) 4 Journal of Intervention and State Building 391, 403.
} 
political forms that are capable both of forestalling the dangers of the present and contributing to a world in which we are able to make free use of our own capacities'. ${ }^{138}$ In her analysis, Agamben's way of '[s] eeing the catastrophe of the present as itself a sign of redemption' is not sufficient as it represents a way to avoid responding to the seeming closure of the political imagination ${ }^{139}$ that we are experiencing, not least within the context of migration. Where does this leave us as international lawyers and as people who wish to change this situation? One cannot help but feel powerless when traditional avenues of contestation through human rights courts and legal challenges to abusive state action appear to be either inaccessible ${ }^{140}$ or ineffective ${ }^{141}$ in their attempt to achieve justice. As I reflect on whether international law may at all in the future become a tool for radical change, Agamben's theory, looking beyond its own limitations, helps us make visible what would otherwise remain uncontested, that is the humanitarian posturing of EU migration policies. For the purposes of the use (and misuse) of international law, it is also useful to identify and ultimately acknowledge the inherent limitations of international law and of the ways in which it is used to reproduce and legitimise violence, ${ }^{142}$ as evidenced in this article on the European Agenda. As scholars, we need to remember that 'reaching automatically for the juridical tools that liberalism offers may leave us without the necessary conceptual or strategic means to understand and counter the techniques of power involved in these new [migration] regimes'. ${ }^{143}$ In seeking for alternative narratives, we must look outside of the traditional toolbox to which we are accustomed, and be sure to avoid precluding the political alternatives and potentialities for change. ${ }^{144}$

\footnotetext{
138 Whyte, supra note $42,7$.

139 ibid.

${ }^{140}$ See e.g. the decision by the General Court of the European Union in NG, NG and NMv European Council, Cases T-192/16, T-193-16 and T-257/16: the declared that 'it lack[ed] jurisdiction to hear and determine the actions brought by three asylum seekers against the EU-Turkey statement' since, it held, 'that measure was not adopted by one of the institutions of the EU' but by the Heads of States or government of the member states. According to the paradoxical interpretation of the court, the meeting on 17 March 2016 was a session of the European Council, as an institution of the EU, to which the representatives of the member states were acting in their capacities as members of that institution. The meeting on 18 March 2016, instead, with the same representatives of the member states and the Turkish Prime Minister was not a meeting of the European Council. General Court of the European Union, Press Release No 19/17 of 28 February 2017.

${ }^{141}$ See the decision by the Hungarian government to ignore the ECtHR decision in Ilias and Ahmed v Hungary.

${ }^{142} \mathrm{H}$ Charlesworth, supra note 3, at 391. See also A Orford, 'The Gift of Formalism' (2004) 15 European Journal of International Law 179. On the specific limits of systemic human rights analyses, see S Marks, 'Human Rights and Root Causes' (2011) 74 Modern Law Review 57.

143 A Orford, 'Biopolitics and the Tragic Subject of Human Rights' in E Dauphinee and C Masters (eds), The Logics of Biopower and the War on Terror: Living, Dying, Surviving (Springer, 2007) at 205.

${ }^{144}$ See S Moyn, Not Enough: Human Rights in an Unequal World (Harvard University Press, 2018) where he argues that, historically, human rights have been a powerless companion to neoliberalism and have essentially posed no threat to market fundamentalism and the harm it has caused because they foreswore the ideal of social equality to focus on sufficient provision, never really challenging or constraining material inequality. See in particular chapters 6 and 7. See also S Moyn, 'Are Human Rights Enough? The Universal Declaration between
} 
Welfare State and Neoliberal Globalization', Vikerkaar Eurozine 24 November 2017 at <https://www.eurozine.com/are-human-rights-enough/>, 5-6. 